https://doi.org/10.17816/MAJ191S124-26

\title{
LIPOPOLYSACCHARIDE-INDUCED IMMUNOLOGICAL STRESS AT EARLY STAGES OF PREGNANCY AFFECTS THE DEVELOPMENT OF GONADOTROPIN RELEASING-HORMONE (GNRH)-PRODUCING SYSTEM
}

\author{
V.M. Ignatiuk, M.S. Izvolskaia
}

Koltzov Institute of Developmental Biology, Russian Academy of Sciences, Moscow, Russia

\author{
ВЛИЯНИЕ ИММУНОЛОГИЧЕСКОГО СТРЕССА, \\ ИНДУЦИРОВАННОГО ЛИПОПОЛИСАХАРИДОМ (E. COLI) \\ НА РАННИХ СРОКАХ БЕРЕМЕННОСТИ, \\ НА РАЗВИТИЕ ГОНАДОТРОПИН-РИЛИЗИНГ ГОРМОН \\ ПРОДУЦИРУЮЩЕЙ СИСТЕМЫ
}

\author{
В.М. Игнатюк, М.С. Извольская \\ ФГБУН «Институт биологии развития им. Н.К. Кольцова» РАН, Москва
}

\begin{abstract}
The aim of the present work was to study the development of afferent bonds between GnRH- and monoaminergic neurons in rat fetuses and to identify possible targets affected by LPS-induced inflammation. The innervation was analyzed using retrograde tracing method with DiI dye. At ED17 and ED21 olfactory bulbs (the area of GnRH migration) are innervated with monoaminergic neurons of septum and in lateral hypothalamus. The GnRH- and monoaminergic neuron interaction zones are sensitive to LPS (E. coli) prenatal exposure, which induces pro-inflammatory cytokine synthesis. We suppose that the olfactory bulbs of fetal forebrain can be a possible area of cytokine influence on GnRH- and monoaminergic neuron interaction.

Keywords: immunological stress; lipopolysaccharide; gonadotropin releasing-hormone- and monoaminergic neurons.

Цель настоящей работы - исследовать формирование афферентных нервных связей между гонадотропин-рилизинг гормон (ГРГ)- и моноаминергическими нейронами мозга плодов крыс в онтогенезе и определить области возможного влияния воспаления, вызванного ЛПС, на их развитие. Иннервацию ГРГ-системы исследовали методом ретроградного мечения нейронов красителем DiI. Показано, что на 17 и 21 дни эмбрионального развития обонятельные луковицы, область миграции ГРГ-нейронов, иннервируются моноаминергическими нейронами септума и латерального гипоталамуса. Области взаимодействия ГРГ- и моноаминергических нейронов были чувствительны к пренатальному воздействию ЛПС (E. coli ), индуцирующему синтез провоспалительных цитокинов. Предполагается, что одной из возможных областей влияния провоспалительных цитокинов на взаимодействие ГРГ- и моноаминергических нейронов могут быть обонятельные луковицы переднего мозга плода.
\end{abstract}

Ключевые слова: иммунологический стресс; липополисахарид; гонадотропин-рилизинг гормон; моноаминергические нейроны.

Introduction. Maternal immunological stress during the pregnancy, induced by bacterial or viral infection, is a frequent phenomenon, while the control of this problem is often restricted by a limited choice of therapy. It can lead to developmental and functional disruptions of many body systems, especially the nervous system, resulting in neuropsychological, immunological, metabolic and reproductive disorders [1, 2]. Inflammation is associated with elevated cytokine levels in both mother and fetus, affecting brain development [3]. According to our previous data, LPS E. coli affects development of GnRH neurons [4]; GnRH is an important signal molecule in the neuroendocrine and immune system interactions. GnRH neurons stem from olfactory placodes outside the brain and migrate along growing nerves in hypothalamus. Their migration into the brain delays after maternal LPS exposure at early stages of pregnancy in rats, which leads in future to suppression of $\mathrm{GnRH}$, gonadotropin and sex steroid synthesis [5]. When GnRH neurons migrate into the forebrain in the base of olfactory bulbs, they get strong neurohumoral stimulation from neural terminals located in this area. We suppose that the LPS-induced disruptions of GnRH system development may affect organization of afferent and efferent neural associations. The aim of the present work was to study the development of afferent bonds between GnRH- and monoaminergic neurons in rat fetuses and to identify possible targets affected by LPS-induced inflammation.

Material and methods. The study was carried out on female Wistar rats with dated pregnancy $(n=4)$. GnRH neuron innervation was analyzed using DiI retrograde tracing method. DiI is a lipophilic fluorescent dye, diffusing laterally in the membranes [6]. DiI crystals were placed at olfactory tubercles of rat fetuses, perfused and fixed with 

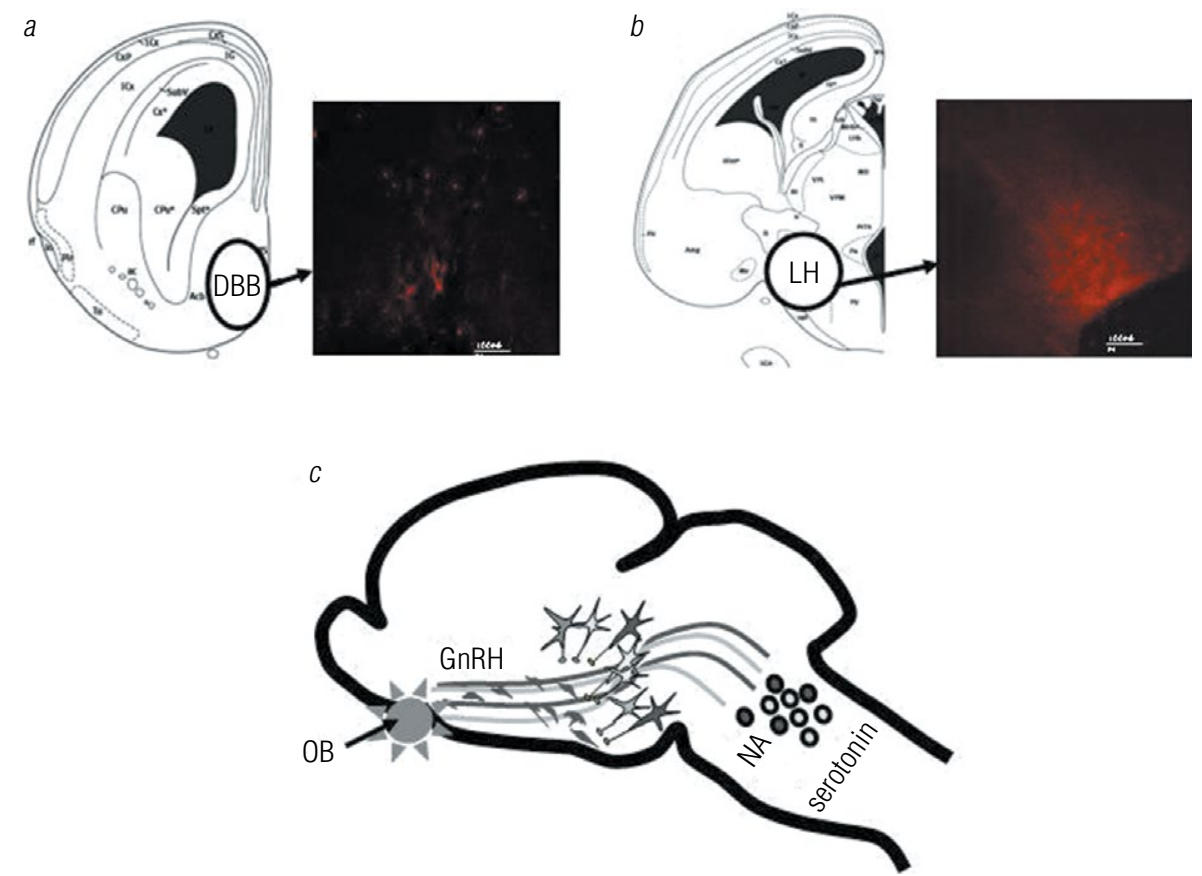

Fig. Afferent bond association with GnRH neurons. $a-b$. Bodies (stained, DiI) of monoaminergic neurons innervating GnRH neurons at ED17 and ED21. c. A model of GnRH and monoaminergic neuron interaction. DBB - diagonal Broca bundle, LH - lateral hypothalamus, NA - noradrenalin, OB - olfactory bulbs - the area of possible LPS impact

paraformaldehyde at embryonic day 17 (ED17) and ED21 $(n=10$ in each group). Within 3 months, serial brain sections were obtained using vibratome and analyzed by confocal microscopy. In special experiments, rats were treated with LPS (E. coli, $50 \mu \mathrm{g} / \mathrm{kg}$ ) intraperitoneally at ED12. All manipulations on animals were approved by the Ethics Committee for Animal Research of the Koltzov Institute of Developmental Biology RAS in accordance with the Recommendations for Laboratory Practice in Russian Federation.

Results and discussion. Main groups of neurons innervating olfactory tubercles at ED17 were detected in septal area and in lateral hypothalamus. At ED21 neural cell bodies were found also in raphe nuclei and midbrain locus coeruleus. $\mathrm{GnRH}$ neurons that migrate into the forebrain are primarily innervated by GABA-ergic neurons located in the septal area. It is also possible that GnRH neurons are innervated by neurons with transitory expression of monoamine synthesis en- zymes, located in septum and lateral hypothalamus, since canonical catecholaminergic neuron groups are located farther in caudal direction. At ED21, the innervation of olfactory bulbs by serotoninergic neurons of raphe nuclei and noradrenergic neurons of locus coeruleus is detected (Fig.). According to preliminary data, the areas of GnRH- and monoaminergic interactions were sensitive to LPS exposure, which seems to be induced by elevated levels of proinflammatory cytokines in fetus. A significant increase of concentration of LIF, MCP-1 and especially IL-6 was detected in maternal and fetal biological fluids. IL-6 receptors are detected along the migration route of GnRH neurons [4].

Conclusion. Therefore, the olfactory bulbs of the fetal brain at E17 and E21 can be one of the possible areas of proinflammatory cytokine impact on GnRH- and monoaminergic neuron interaction.

Funding. This work was funded by Government Program of Basic Research (No. 0108-2018-0002).

\section{References}

1. Wang S, Yan JY, Lo YK, et al. Dopaminergic and serotoninergic deficiencies in young adult rats prenatally exposed to the bacterial lipopolysaccharide. Brain Res. 2009;1265:196-204.

2. Zakharova L. Perinatal stress in brain programming and pathogenesis of psychoneurological disorders. Biology Bulletin. 2015;42(1):12-20.

3. Girgis RR, Kumar SS, Brown AS. The cytokine model of schizophrenia: emerging therapeutic strategies. Biol. Psychiatry. 2014;75:292-299.

4. Sharova VS, Izvolskaia MS, Zakharova LA. Lipopolysaccharide-induced maternal inflammation affects the Gonadotropin-Releasing Hormone neuron development in fetal mice. Neuroimmunomodulation. 2015;22:222-232.

5. Izvolskaia MS, Tillet Y, Sharova VS, et al. Disruptions in the hypothalamic-pituitary-gonadal axis in rat offspring following prenatal maternal exposure to lipopolysaccharide. Stress. 2016;19:198-205.

6. Makarenko IG. DiI tracing of the hypothalamic projection systems during perinatal development. Front. Neuroanat. 2014;8:144. 